\title{
DEKONSTRUKSI STRUKTUR NOVEL OLENKA KARYA BUDI DARMA
}

\author{
Muhammad Nur Hanif \\ Independent Researcher \\ muhnurhanif07@gmail.com
}

Artikel diterima: 31 Mei 2020

Artikel direvisi: 13 Juli 2020

Artikel disetujui: 26 Agustus 2020

\begin{abstract}
Abstrak
Penelitian-penelitian terdahulu terhadap novel Olenka menyatakan bahwa tokoh-tokoh dalam novel tersebut tidak memiliki eksistensi; tidak hadir. Dari sudut pandang semacam itu, narator kemudian tampak seolah noneksistensialis dan antilogosentris. Meskipun demikian, penelitian-penelitian tersebut mengimplikasikan idealisasi atas eksistensi itu sendiri. Dengan menggunakan perspektif Jacques Derrida, penelitian ini berupaya menggugat kembali temuan-temuan tersebut melalui analisis konstruksi struktur dan dekonstruksi struktur novel Olenka. Sebab, bagi Derrida, implikasi idealisasi eksistensialisme seperti identitas (tokoh) yang tetap, stabil, tunggal, serta murni mengindikasikan logosentrisme. Penelitian ini menemukan logosentrisme yang beroperasi dalam konstruksi jaringan oposisi hierarkis. Konstruksi itu sering kali tersembunyi dan terepresi. Penyembunyian atau represi tersebut dilakukan melalui eksklusi dan inklusi. Struktur novel Olenka dikonstruksi secara logosentris dengan pemosisian seorang tokoh bernama Wayne Danton sebagai prototipe logos (senter atau pusat). Setelah prosedur dekonstruktif diterapkan, dapat diamati bahwa Wayne Danton ternyata tidak pernah ada atau hadir secara murni dan penuh sebab identitasnya selalu bergerak, berubah, serta terus-menerus mengacu dan bergantung pada identitas (tokoh) lain sehingga tidak pernah mencapai final. Dengan kata lain, penelitian ini mengungkap intensi narator nov-
\end{abstract}

\begin{abstract}
Previous studies of Olenka's novels state that the characters in the novel lacked existence; not present. From such a perspective, the narrator then appears to be a non-existentialist and anti-logocentric. However, these studies imply idealization of existence itself. By using the perspective of Jacques Derrida, this study seeks to recriticize these findings through an analysis of the construction and deconstruction of Olenka's novel structure. Because, for Derrida, the implication of existentialism idealization such as identity (character) which is permanent, stable, single, and pure indicates logocentrism. This study found logocentrism which operates in the construction of hierarchical opposition networks. The construction is often hidden and repressed. The concealment or repression is carried out through exclusion and inclusion. The structure of Olenka's novel is constructed logocentrically by positioning a character named Wayne Danton as the prototype of the logos (central or center). After the deconstructive procedure is implemented, it can be observed that Wayne Danton apparently never existed or was present purely and fully. Because, his identity is always moving, changing, and constantly referring to and dependent on the identity of other (figures) so that it never reaches the final. In other words, this study reveals the intention of Olenka's narrator novel towards logocentrism.
\end{abstract}

Keywords: logocentrism, deconstruction, identity, exclusion, inclusion

\section{Pendahuluan}

Budi Darma merupakan salah seorang di antara sedikit penulis Indonesia yang memiliki kiprah akademik yang cukup cemerlang. Dia 
lulus dari UGM pada 1963 dengan memperoleh gelar Bintang Bhakti Wisuda. Atas beasiswa dari East West Centre, Budi Darma belajar ilmu budaya dasar di University of Hawai, Honolulu (1970-1971). Pada 1974, dia menempuh studi di Indiana University, Bloomington, AS, dan meraih gelar Master of Arts pada 1976 melalui tesis berjudul The Death and The Alive. Selanjutnya, dengan disertasi Character and Moral Judgement in Jane Austin's Novel, Budi Darma memperoleh gelar doktor di Indiana University, Bloomington, 1976-1980. Capaian Budi Darma dalam kepenulisan sastra tidak kalah gemilang.

Naskah Olenka dinyatakan sebagai pemenang utama Sayembara Roman Dewan Kesenian Jakarta pada 1980. Setelah terbit pada 1983, novel Olenka lagi-lagi mendapat hadiah sastra, saat itu, dari DKJ. Tampaknya, novel Olenka memperoleh capaian lebih mentereng daripada dua novel Budi Darma yang terbit setelahnya, yakni Rafilus (terbit pada 1988) dan Ny. Talis (terbit pada 1996). Dia pun menerima Anugerah Seni dari pemerintah RI melalui Mendikbud pada 15 Juni 1993. Dia kemudian dinyatakan sebagai warga Surabaya berprestasi di bidang kesastraan dua kali berturut-turut pada 1987 dan 1988. Pada 2005, Budi Darma akhirnya memperoleh penghargaan Katulistiwa Literary Award Freedom Institute.

Dalam karya-karyanya, Budi Darma sering memanfaatkan nama tokoh sebagai judul. Dalam kumpulan cerpen Orang-Orang Bloomington (2016), kecuali “Laki-Laki Tua Tanpa
Nama" dan "Keluarga M", cerpen-cerpennya diberi judul dengan menggunakan nama tokoh, yakni "Joshua Karabish"; "Orez”; "Yorrick”; "Ny. Elberhart"; dan "Charles Lebourne". Sekalipun "Laki-Laki Tua Tanpa Nama” dan "Keluarga M" bukanlah nama, keduanya tetap merujuk pada identitas tokoh. Judul-judul yang mengacu pada tokoh juga dapat dilihat dalam kumpulan cerpen Kritikus Adinan (2017), misalnya, "Penyair Besar, Penyair Kecil"; "Sahabat Saya Bruce"; "Kritikus Adinan"; "Laki-Laki Setengah Umur"; dan "Bambang Subali Budiman". Dalam ketiga novelnya, bahkan nama tokoh secara konsisten tercantum sebagai judul, yaitu Olenka (1983), Rafilus (1988), dan Ny. Talis (1996).

Identitas tokoh-tokoh yang begitu menonjol tersebut akhirnya menjadi titik tolak yang menginspirasi tulisan ini. Adapun objek yang dipilih kemudian adalah novel Olenka sebab dilihat dari sisi capaiannya, novel Olenka dapat dikatakan sebagai novel monumental dalam kepengarangan Budi Darma jika dibandingkan dengan dua novelnya yang lain. Tentu, tilisan ini bukan tulisan pertama yang berupaya mengupas seluk-beluk tokoh-tokoh dalam novel tersebut.

Tirto Suwondo, misalnya, merupakan peneliti yang cukup sering membahas karyakarya Budi Darma, khususnya novel Olenka. Namun demikian, berdasar naskah-naskah yang ditemukan, tulisan-tulisannya cenderung serumpun. Misalnya, novel Olenka yang disinggung di artikel "Gauhati" Budi Darma: Senantiasa Gagal Mencari Jati Diri" dalam antologi penelitiannya, Membaca Sastra, Membaca 
Poetika : Jurnal Ilmu Sastra

Vol. 8 No. 1, Juli 2020
DOI $10.22146 /$ poetika.56473

ISSN 2338-5383 (print) ; 2503-4642 (online)
Kehidupan (2011), menjadi eksplorasi atas tesisnya yang berjudul Olenka: Tinjauan Dialogis (2000) yang dibukukan (diterbitkan) menjadi Suara-Suara yang Terbungkam (2001). Tesis tersebut pun melenggang dan nongkrong di Jurnal Pangsura pada Juli 2001 berupa artikel berjudul "Olenka, Chairil Anwar, dan Sartre: Kajian Dialogis". Persoalan kegagalan mencari jati diri juga menjadi tema dalam majalah sastra Horison edisi Januari 2002 ketika Suwondo mengulas beberapa karya Budi Darma maupun proses kreatif Budi Darma sendiri. Singkatnya, berkaitan dengan novel Olenka, Suwondo berupaya memaparkan kegagalan tokoh-tokoh dalam mencari jati diri. Oleh karena itu, setelah dilakukan penyortiran, yang diulas hanyalah naskah Tirto Suwondo yang dimuat dalam Jurnal Pangsura, Bilangan 13/Jilid 7, JuliDesember 2001.

Penelitian tersebut bermula atas pernyataan bahwa tidak ada tuturan tanpa hubungan dengan tuturan lain. Banyak indikasi yang menunjukkan novel Olenka berhubungan (berdialog) dengan teks-teks lain. Novel itu akhirnya menjadi medan laga berbagai teks. Meski demikian, dalam penelitian tersebut, yang disorot hanyalah hubungan tekstual antara novel Olenka dengan naskah-naskah Chairil Anwar dan Jean-Paul Sartre. Pertimbangannya, teks yang berasal dari dua tokoh itu memiliki signifikansi yang tinggi (dominan). Sebagai landasan teori intertekstualitas, Suwondo sering mengutip Mikhail Bakhtin dan Umar Junus dalam tu- lisannya. Hasilnya, penelitian tersebut mengungkapkan, novel Olenka dan sajak-sajak Chairil Anwar mengandung unsur penerimaan dan penolakan. Artinya, ada beberapa unsur sajak yang diterima dan ditolak oleh novel Olenka. Dengan kata lain, kedua teks mencerminkan adanya persamaan dan perbedaan. Persamaannya, "aku lirik" dalam sajak maupun "saya" dalam novel sama-sama berhadapan dengan absurditas hidup. Perbedaannya berkenaan dengan kematian. "Aku lirik" penuh kesiapan (tanpa rasa cemas), sedangkan "saya" dalam novel terus berada dalam kebimbangan (penuh ketidakpastian). Dalam keadaan demikian, tokoh "saya" (Fanton Drummond) terus berusaha mencari jati dirinya.

Selanjutnya, dilihat dari sikap, perilaku, dan pemikiran tokoh-tokohnya, menurut Suwondo, novel Olenka tampak diciptakan untuk menanggapi pemikiran Sartre. Hal itu terlihat jelas pada penampilan Fanton Drummond. Di satu sisi, Fanton ditampilkan sebagai penganut kebebasan-sebagaimana yang dikembangkan Sartre-yang tidak mengakui "kekuatan di luar dirinya", tetapi di sisi lain, penampilannya selalu dibayangi kehadiran $\mathrm{Tu}-$ han sebagai tanda adanya kekuatan lain. Apabila jati diri dapat dipahami sebagai identitas, secara tidak langsung Suwondo mengatakan bahwa Fanton belum memiliki identitas. Misalnya, dia mengungkapkan bahwa Fanton terus berusaha mencari jati dirinya. Suwondo juga menempatkan kebebasan sebagai nilai vital eksistensi manusia. Bahkan, Suwondo menegaskan, manusia tidak bisa lari dari bayangan ke- 
hadiran Tuhan sebagai nilai eksistensi tertinggi, absolut, dan universal.

Melalui perspektif Derrida, pernyataanpernyataan semacam itu mengandung bias logosentrisme. Perkara "nilai-nilai"-baik manusia maupun Tuhan; yang bersifat lebih rendah maupun lebih tinggi-tersebut tidak tersorot oleh Suwondo. Dia justru sibuk membahas persamaan dan perbedaan tekstual antara tokoh-tokoh dalam novel Olenka dan sajak-sajak Chairil Anwar. Akhirnya, tulisan ini berbeda dengan tulisan Suwondo karena percaya bahwa nilai-nilai yang diasosiasikan dengan absoludity, universalitas maupun puncak tertinggi selalu mengandung logika kontradiktif dalam dirinya sendiri. Dengan kata lain, tulisan ini akan membahas hal-hal yang telah terabaikan dalam penelitian Suwondo.

Penelitian terhadap novel Olenka juga dilakukan oleh Indraningsih dan selesai menjadi tesis pada 1996 dengan judul "Eksistensi Manusia dalam Rafilus dan Olenka Karya Budi Darma: Sebuah Kajian Semiotik". Penelitian tersebut bertujuan mengungkapkan makna eksistensi manusia dalam novel Rafilus dan Olenka karya Budi Darma. Dengan menggunakan perspektif semiotik dalam paradigma strukturalisme dan eksistensialisme (merujuk filsuf-filsuf seperti Jonathan Culler, Umberto Eco, dan Jean-Paul Sartre), Indraningsih meyakini bahwa karya sastra adalah penanda yang selalu merefleksikan petanda. Petanda sendiri dipahami sebagai sesuatu yang berada di luar struktur karya, misalnya, kehidupan masyarakat. Oleh karena itu, dia menggunakan metode semiotik-struktural untuk mengkaji struktur dua novel tersebut. Menurut dia, novel Rafilus dan Olenka memiliki struktur yang terbentuk atas kesatuan antarunsur yang utuh. Keutuhan tersebut kemudian dipahami sebagai syarat kajian semiotik. Lewat kajian tersebut, makna eksistensi manusia dalam novel Rafilus dan Olenka dapat dilihat dan dibahas. Indraningsih kemudian memperoleh kesimpulan bahwa kedua novel membicarakan masalah-masalah yang dihadapi manusia dalam mewujudkan dan mempertahankan eksistensi.

Karena identik dengan kebebasan, eksistensi seseorang selalu berbenturan dengan kebebasan orang lain. Oleh karena itu, hanya subjek yang dianggap eksis. Asumsinya, subjek lebih berhak memiliki kebebasan daripada objek. Semua tokoh lalu ingin menjadi subjek dengan cara mengobjektivikasi tokoh-tokoh lain, menghilangkan eksistensi tokoh-tokoh lain. Akibat masalah-masalah tersebut, menurut Indraningsih, tokoh-tokoh dalam novel Rafilus dan Olenka menyadari bahwa Tuhanlah nilai eksistensi tertinggi dan universal; keadaan asal mula sebelum eksistensi mendapatkan makna sekaligus keadaan akhir tempat eksistensi melabuhkan makna; penjamin segala makna.

Jika ditinjau kembali, pertama-tama, Indraningsih melakukan penelitian melalui metode semiotik-struktural. Kendati demikian, dia lalu membangun kesimpulan universal terkait dengan eksistensi. Padahal, meski di satu sisi mengakui keterhubungan penanda dan 
petanda, di lain sisi, dia juga mengakui keterpisahan keduanya: terhubung karena penanda (novel) hanya merefleksikan petanda (kehidupan masyarakat) yang berada di luar (struktur novel); terpisah karena aktivitas refleksi tersebut. Hal tersebut memunculkan kontradiksi. Ditambah lagi, Indraningsih menyatakan bahwa struktur novel Rafilus dan Olenka berdiri atas kesatuan atau keutuhan antarunsur-tentu, yang dimaksud unsur-unsur tersebut adalah unsur -unsur semiotika, yakni penanda dan petanda. Padahal, dia sendiri yakin bahwa penanda tidak pernah seruang dengan petanda. Bagaimana bisa unsur-unsur tersebut kemudian dikatakan utuh dan bersatu? Hal itu tidak dibahas oleh Indraningsih.

Di lain segi, Indraningsih mengatakan bahwa eksistensi harus diwujudkan dan dipertahankan. Pernyataan tersebut menampakkan sebuah paradoks. Di satu sisi, dilihat dari kata "dipertahankan", Indraningsih percaya bahwa eksistensi ada (korporat). Paradoksnya, dia kemudian mengungkapkan bahwa eksistensi harus diwujudkan. Hal tersebut justru mengindikasikan bahwa eksistensi adalah sesuatu yang metafisik (inkorporat). Oleh karena itu, menurut Indraningsih, eksistensi harus ditransformasikan sebagai sebuah fisik atau wujud supaya eksis. Bentuk transformasi tersebut adalah subjek yang bebas. Subjek, dengan predikat kebebasannya, lalu menjadi pusat yang mendasari struktur dalam novel Rafilus dan Olenka. Karena ternyata manusia (subjek) sering bermasalah, akhirnya pusat itu kembali pada wujud eksistensi yang paling substansial dan universal, yakni Tuhan.

Tulisan ini berbeda dengan penelitian yang dikerjakan Indraningsih. Selain hendak membahas hal-hal yang dikesampingkan dalam penelitian tersebut-misalnya, logika yang menyatakan kebergantungan subjek pada objek maupun interkoneksi tiada akhir antara kebebasan dan kecemasan, ketenangan dan keterasingan, yang superior dan yang inferior, serta seterusnya-tulisan ini akan menentang segala hal yang dianggap sebagai pusat dalam sebuah struktur.

Melalui penelitian-penelitian terdahulu tersebut, tampak kecenderungan bahwa identitas tokoh-tokoh dalam karya Budi Darma dipahami sebagai sesuatu yang tetap (fixed) dan final. Pertanyaan kedua penelitian mengenai mengapa identitas tokoh tidak eksis dalam dunia relasi, secara bersamaan, justru mengimplikasikan adanya nilai ideal bahwa identitas eksis, hadir, atau ada. Akhirnya, identitas menjadi basis atau landasan absolut dan stabil sebuah struktur dalam sistem relasi.

Menurut Jacques Derrida, segala hal yang mendasarkan diri pada sesuatu yang hadir, absolut, stabil, tetap, tunggal, atau final-baik kesadaran, eksistensi, kebebasan, manusia, maupun identitas-selalu mengandung logika kontradiktif, inkonsisten, dan tidak stabil yang dapat menghancurkan dirinya sendiri. Oleh karena itu, penelitian ini hendak menggunakan perspektif Derrida untuk mengamati perihal yang dijadikan dasar, landasan, atau pusat 
struktur serta membuktikan bahwa hal-hal seperti itu tidak ada: tidak murni dan tidak penuh-baik yang dikonstruksikan sebagai dasar struktur novel Olenka maupun struktur itu sendiri.

Melalui perspektif Derrida, tulisan ini mendeteksi suatu permasalahan pokok, yakni (identitas) elemen-elemen atau unsurunsur yang diasumsikan hadir, absolut, stabil, tetap, tunggal, atau final serta pengonstruksiannya sebagai fundamen struktur. Namun demikian, karena perbedaan pendekatan, tentu, tulisan ini tidak begitu saja menerima formula struktur novel Olenka dari penelitian-penelitian sebelumnya. Dengan begitu, tulisan ini membahas dua hal. Pertama, konstruksi struktur novel Olenka karya Budi Darma. Kedua, dekonstruksi struktur novel Olenka karya Budi Darma.

Tulisan ini akan menggunakan kerangka teori Jacques Derrida, terutama yang termaktub dalam buku Speech and Phenomena (1973) dan Of Grammatology (1976). Sebagai acuan sekunder, tulisan ini juga melibatkan buku yang ditulis Arthur Bradley, Derrida's of Grammatology (2008). Secara langsung maupun tidak langsung, analisis penelitian ini dikerjakan dengan mengikuti koridor teoretis berdasar gagasan dalam buku-buku tersebut untuk menjawab pertanyaanpertanyaan yang telah dirumuskan.

Melalui Of Grammatology (1976), setidaknya terdapat dua fokus yang ditekankan Derrida. Pertama, dia mengungkapkan bahwa tradisi filsafat Barat adalah sebuah meta- physics of presence yang secara konsisten dan dogmatis menempatkan momen kehadiran murni dan langsung (pure and unmediated presence) sebagai nilai tertinggi dan universal. Kedua, dia menyatakan bahwa mode yang mendefinisikan metaphysics of presence tersebut adalah logosentrisme: tuturan (speech) ditakdirkan sebagai kendaraan istimewa presence, sedangkan tulisan (writing) hanya merepresentasikan mediasi atau penundaan presence. Derrida kemudian berpendapat bahwa komitmen metafisik dan logosentris terhadap tuturan bergantung pada kontradiksi atau ketegangan yang fondasional: seluruh bahasa-tuturan maupun tulisan-dikarakterisasi oleh mediasi esensial yang diberikan metafisika secara historis kepada "tulisan" saja. Apabila jaminan kebenaran-tuturan-telah dicemari tulisan, terdapat implikasi bahwa tidak ada akses ke suatu presence yang sepenuhnya terlepas dari mediasi linguistik. Dengan demikian, menurut Derrida, teori tanda linguistik merepresentasikan suatu gejala yang privileged: tanda kemudian menjadi situs atas pertanyaan Derrida terhadap logosentrisme (Bradley, 2008:41-42).

Bagi Derrida, tanda linguistik merupakan titik masuk logika metafisika secara keseluruhan. Teori tanda linguistik yang logosentris didasarkan pada oposisi antara "penanda" dan "petanda". Oposisi tersebut pada gilirannya mengarah ke jaringan oposisi yang lebih luas yang mengandung metafisika dalam keseluruhannya: soul-body, infinite-finite, transcendental-empirical (Bradley, 2008:44).

Logosentrisme teori tanda linguistik di- 
awali dari pemikiran Aristotle (On Interpretation). Menurut dia, spoken word (kata terucap) adalah simbol pengalaman mental, sedangkan written word (kata tertulis) merupakan simbol kata terucap. Suara lebih dekat dengan petanda, baik ditentukan secara ketat sebagai sense (thought atau lived) maupun lebih longgar sebagai benda (things). Sementara itu, penanda tertulis selalu teknis, representatif, serta tidak memiliki makna konstitutif. Penanda tertulis adalah turunan dari suara yang tidak bisa dipisahkan dari mind atau thought sebagai petanda. Derivasi tersebut merupakan asal mula gagasan "penanda". Gagasan penanda pun selalu mengimplikasikan di dalam dirinya sendiri perbedaan antara penanda dan petanda. Gagasan itu tetap dalam warisan logosentrisme yang juga merupakan fonosentrisme: kedekatan absolut antara suara dan being (wujud), suara dan makna being, serta suara dan idealitas makna (Derrida, 1976:11-12).

Menurut Derrida, momen penting lain dalam sejarah tanda berada pada zaman kreasionisme atau infinitisme Kristiani: bertemunya teologi Kristiani dan metafisika Yunani. Melalui perbedaan teologis antara dunia sensible dan intelligible (dunia "ini" dan dunia "lain"), perbedaan antara penanda dan petanda dalam linguistik modern muncul. Tanda terucap dan tanda tertulis (penanda) hanyalah tanda dari petanda, yaitu dunia yang ada sebelumnya, dan terlepas darinya. Referensi penanda pada petanda memungkinkan "penempatan diri" dalam intelligibility -nya sebelum "keterjatuhan" atau pengusirannya ke wilayah eksterior, yakni dunia sensible; di sini, di bawah ini (here and below). Sebagai wajah murni intelligibility, petanda mengacu langsung pada logos absolut dan menjadi kesatuannya. Logos absolut tersebut adalah subjektivitas kreatif tanpa batas dalam teologi abad Pertengahan: wajah intelligible tanda tetap berpaling ke arah wajah Tuhan. Yang menandai Tuhan pada teologi skolastik abad Pertengahan adalah penyebab pertama (Causa sui); penggerak yang tidak bergerak (unmoved mover); singkatnya, sesuatu yang hadir secara mutlak yang menjamin segala makna (Bradley, 2008:45-46; Derrida, 1976:13).

Pendapat Derrida mengenai sejarah logosentrisme perlu diperjelas. Tujuan Derrida adalah memperlihatkan logosentrisme dalam dekonstruksi. Dia mempertanyakan konstruksi logosentrisme-kisah "resmi" yang menceritakan dirinya sendiri yang terorganisasiserta menunjukkan betapa hal tersebut dapat direkonstruksi secara lain (Bradley, 2008:47).

Bagi Derrida, tujuan dekonstruksi adalah mengartikulasikan kondisi-yang sering kali tersembunyi atau terepresi-yang memungkinkan struktur terbentuk di tempat pertama. Dekonstruksi menandai peruntuhan, penguraian, dan pendesedimentasian struktur untuk memahami bagaimana suatu "ansambel" dibangun dan untuk merekonstruksinya (Bradley, 2008:42-43).

Dekonstruksi bukan memperlakukan teks dari "luar", tetapi lebih kepada pengungkapan bahwa setiap teks dikonstruksi secara internal. 
Tujuan pembacaan Derrida terhadap teks yang diunggulkan dalam logosentrisme bukanlah untuk menciptakan posisi pengetahuan atau otoritas yang lebih superior, tetapi untuk mengusik kontradiksi imanen di dalam teks itu sendiri: Husserl tidak dikritik oleh siapa pun kecuali Husserl sendiri dan Lévi-Strauss tidak dikritik oleh siapa pun kecuali Lévi-Strauss sendiri. Dekonstruksi setidaknya merupakan nama dari suatu alat atau instrumen yang diaplikasikan terhadap teks, kemudian terhadap kondisi dasar setiap teks-sekalipun tersembunyi atau terepresi. Setiap teks didasarkan pada jaringan mediasi, perbedaan, serta jejak yang terus bergerak. Oleh karena itu, bagi Derrida, proses membaca bukan saja masalah yang secara aktif mendekonstruksi logosentrisme, tetapi juga menunjukkan bahwa metaphysics of presence sudah berada dalam proses selfdeconstruction, itu pun jika dia mempunyai "diri": metaphysics of presence tidak memiliki ground atau fondasi yang penuh dan "hadir" (present) untuk mendasari dirinya sendiri; dia berada dalam ketidakstabilan dan ketidakpastian (contingency) yang permanen (Bradley, 2008:43).

Metafisika beroperasi dengan menciptakan serangkaian oposisi dan hierarki biner; istilah-istilah superior seperti tuturan, pikiran, dan yang ideal diidentikkan dengan kehadiran yang murni dan tanpa mediasi, sedangkan istilah-istilah yang inferior seperti tulisan, tubuh, dan yang material disamakan dengan mediasi, hilangnya kehadiran, dan ketidakhadiran (Bradley, 2008:76).

Sementara itu, Faruk (2012:215-218) mengingatkan betapa pentingnya pemahaman atas metafora dalam prosedur dekonstruksi. Sebagaimana diketahui, dekonstruksi hampir selalu melibatkan bahasa. Padahal, bahasa sendiri tidak hanya mencerminkan realitas. Bahasa bekerja dengan mentransfer satu realitas ke realitas lain sehingga benar-benar bersifat metaforis. Oleh karena itu, kritik dekonstruktif mengambil metafora dengan sungguh-sungguh. Karena metafora tidak dapat direduksi menjadi kebenaran, strukturnya sendiri merupakan bagian teks. Metafora merupakan salah satu jalan bagi Derrida untuk menemukan karakter teks yang mengandung dekonstruksi diri. Teks biasanya dibangun bukan atas dasar argumen logis, melainkan atas dasar metafora. Berangkat dari metafora tersebut, lalu mengembangkannya sampai pada batas maksimal, kritik dekonstruktif dapat menemukan kerusakan pada argumen logisnya. Pembacaan cermat dekonstruktif, setelah menginterogasi sebuah teks, akan menghancurkan pertahanannya serta menunjukkan bahwa seperangkat oposisi berpasangan ditemukan di dalamnya. Oposisi itu tersusun secara hierarkis dengan menempatkan salah satu pasang sebagai yang istimewa. Dekonstruktor kemudian menunjukkan bahwa identitas yang istimewa itu bergantung pada pengeksklusiannya atas yang lain dan menunjukkan keutamaan justru terletak pada yang justru disubordinasikan.

Sumber data dalam penelitian ini adalah novel Olenka. Pengumpulan data dilakukan 
dengan menggunakan metode studi pustaka. Data-data dikumpulkan dengan teknik simak catat. Adapun data-data yang dimaksud meliputi kata, kalimat, paragraf, wacana, atau paradigma yang ditemukan dalam novel Olenka. Data-data tersebut berkaitan dengan jaringan oposisi hierarkis, sikap dan paradigma tokohtokoh, relasi antartokoh, sikap dan paradigma narator, serta teknik pengonstruksian struktur novel. Setelah terkumpul, data-data itu disortir. Penyortiran dilakukan demi memperoleh data yang akurat sebagai bahan kerja analisis dekonstruksi berdasar perspektif Jacques Derrida.

Analisis data dilakukan dengan menghubungkan data-data yang tercakup dalam dua variabel penelitian. Analisis kemudian dikerjakan secara induktif melalui beberapa langkah berdasar prosedur dekonstruksi menurut Derrida. Adapun langkahlangkah tersebut adalah sebagai berikut. Pertama, melakukan pembacaan heuristik untuk memetakan jaringan oposisi dan kandungan hierarki di dalam struktur novel. Kedua, mengungkap teknik narator dalam mengonstruksi struktur novel melalui jaringan oposisi; dimulai dari memeriksa paradigma tokoh demi tokoh, paradigma narator sendiri, implikasi perbedaannya, hingga dugaan bahwa paradigma narator "bersembunyi" di balik paradigma para tokoh. Ketiga, mengamati metafora dan ironi yang dimainkan narator untuk merepresi aspek logosentris dalam konstruksi struktur novel. Keempat, menunjukkan kontradiksi dan paradoks dalam logi- ka logosentris narator secara skematis. Kelima, membuktikan bahwa struktur yang dikonstruksi narator secara logosentris runtuh atau rusak oleh logika yang dikandungnya sendiri.

\section{Konstruksi Struktur Novel Olenka}

Selain dari berbagai metafora dan ironi, jejak paradigma narator terlacak dari tatanan jaringan oposisi. Narator mengemas beragam jaringan oposisi tersebut secara naratif dalam paradigma tokoh-tokohnya. Otomatis, paradigma narator sendiri tersembunyi dan terepresi di balik teks. Dengan cara semacam itulah struktur novel Olenka tersedimentasi. Namun demikian, seperti diungkapkan Saussure yang disetujui Derrida, setiap tanda linguistik hanya mendapatkan maknanya melalui perbedaannya dengan tanda linguistik lain. Oleh karena itu, makna struktur novel Olenka dapat diamati melalui pembacaan heuristis terhadap paradigma tokoh-tokoh. Karena paradigma tokoh-tokoh pun berbeda-beda, tulisan ini kemudian dituntut untuk mengamati perbandingan antartokoh. Dengan begitu, pola struktur novel Olenka yang dikonstruksi oleh narator akhirnya terlihat.

Berbicara tentang perbandingan antartokoh, narator tampaknya menciptakan seorang tokoh yang lebih istimewa daripada tokoh-tokoh lain. Tokoh tersebut adalah Wayne Danton. Keistimewaan yang paling jelas adalah cerita tokoh Wayne berakhir dengan keberhasilan. Padahal, cerita tiga tokoh lainnya (Fanton, Olenka, dan MC) berakhir dengan kegagalan dan kesengsaraan. Selain itu, Wayne berhasil 
meraih tujuannya memiliki identitas pengarang, sedangkan tokoh lain tersepaksepak oleh keadaan sehingga hidup mereka tidak pernah mencapai tujuan.

Fanton, misalnya, karena kesulitan mendapatkan Olenka, hidupnya hanya mengikuti orang lain. Identitasnya berubahubah. Akhirnya, Fanton tersesat dan kebingungan sehingga makna hidup yang diraihnya hanyalah makna yang fana. Olenka pun demikian. Karena sejak awal tidak memiliki tujuan yang jelas, dia mengikuti orang lain. Akibatnya, tujuan yang baru ditetapkan Olenka belakangan justru mendefinisikan dia sebagai barang murah. Hidupnya tidak bermakna dan tidak berarti. Begitu pula MC. Awalnya, dia memang memiliki keteguhan memegang prinsip. Kendati begitu, dia tidak mampu menahan pahitnya kenyataan sehingga menyingkirkan prinsip tersebut. Akhirnya, MC sengsara dalam kesendirian serta tidak memperoleh makna apa pun. Melihat kenyataan-kenyataan tekstual itu, dapat disimpulkan bahwa makna, pusat, atau senter dalam struktur novel Olenka yang dikonstruksi narator bersemayam dalam diri tokoh Wayne.

Keberhasilan Wayne tentu menandakan suatu gejala privilege. Gejala semacam itulah yang menjadi situs atas pertanyaan Derrida terhadap logosentrisme. Derrida kemudian menyatakan bahwa logosentrisme adalah mode yang mendefinisikan metaphysics of presence. Berangkat dari ungkapan tersebut, novel Olenka dapat dikatakan logosentris. Di lain sisi, terkait dengan metaphysics of presence dalam sejarah tanda, tanda dibagi menjadi dua, yakni petanda (makna) dan penanda (sesuatu yang mengacu pada petanda atau makna). Penanda pun terbagi menjadi dua, yakni suara dan tulisan. Akan tetapi, ada hierarki: suara lebih diistimewakan daripada tulisan. Suara juga dianggap lebih dekat dengan petanda karena melibatkan sesuatu yang hadir; sedangkan tulisan hanya citra, turunan, atau penanda dari suara sehingga dianggap menghilangkan sesuatu yang hadir itu. Dengan kata lain, hanya suaralah yang mengacu petanda secara langsung, murni, dan alamiah. Yang kemudian menjadi poros utama dalam metaphysics of presence tentu saja adalah sesuatu yang hadir, baik berupa penutur maupun subjek.

Seperti Saussure, Rousseau, dan LéviStrauss sebagai filsuf-filsuf yang dikatakan Derrida masih terjebak pada metaphysics of presence, narator novel Olenka pun dapat dianggap demikian. Narator "memenangkan" Wayne melalui pengistimewaan stabilitas unsur-unsur oposisi yang relatif identik dengan karakter petanda dalam paradigma logosentrisme. Di sisi lain, tokoh Fanton, Olenka, dan MC sengsara atau "dikalahkan" narator melalui narasi instabilitas unsur-unsur oposisi yang identik dengan karakter penanda.

Jika ditinjau kembali, unsur-unsur oposisi yang kemudian memenangkan Wayne adalah [visi, bakat, dan klasik]; [independensi]; serta [subjek dan tuan]. Sementara itu, unsur-unsur yang menjadi karakter petanda menurut pandangan logosentris Saussure, Rousseau, dan 
Lévi-Strauss sebagaimana dibahas dalam subbab kerangka teori, antara lain: [tunggal, tetap, unik, dan puas]; [penuh, cukup, dan lengkap]; serta [hadir, murni, dan ideal]. [Visi, bakat, dan klasik] identik dengan [tunggal, tetap, unik, dan puas]. Satu-satunya "visi" dalam hidup Wayne adalah memiliki identitas seorang pengarang. Wayne juga merasa "bakat"-nya tidak pernah mengindikasikan "bakat" apa pun kecuali "bakat" seorang pengarang. "Visi" dan "bakat” Wayne kemudian dapat dikatakan "tetap"; tidak berubah. Dalam perjalanannya, bahkan Wayne berhasil mendapatkan identitas pengarang "klasik". Selain memberikan rasa "puas" kepada Wayne, identitas tersebut dinilai "unik". Sebab, Wayne juga merasa spesial karena identitas itu. Akhirnya, baik sebagai pengarang biasa maupun pengarang "klasik", Wayne memiliki identitas "tunggal", yakni identitas pengarang! Sejak awal kemunculan Wayne hingga akhir ceritanya, identitas tersebut tidak pernah berubah.

Selanjutnya, [independensi] berkaitan dengan [penuh, cukup, dan lengkap]. Setelah merasa telah menemukan bakat, Wayne tidak memerlukan siapa pun dalam urusan kepengarangannya. Dia memilih "independensi" karena merasa "penuh", “cukup”, dan "lengkap". Apalagi, Wayne merasa dapat menulis dengan lebih baik dalam "independensi”. Dunia relasi akhirnya menjadi pengganggu bagi Wayne.

Berikutnya, [subjek dan tuan] identik dengan [hadir, murni, dan ideal]. Berdasar narasi dalam novel Olenka, satu-satunya tokoh yang ditampilkan berhasil menjadi "subjek" adalah Wayne. Karena identitasnya sebagai pengarang yang spesial, Wayne pun secara alamiah menjadi "tuan". Capaian menjadi "subjek" menunjukkan bahwa tokoh Wayne lebih dekat dengan petanda atau makna. Seperti penutur, "subjek" merepresentasikan sesuatu yang "hadir", yang berhak atas makna, serta yang memiliki ikatan murni dengan petanda. Wayne juga "murni" karena menetapkan tujuan menurut kehendaknya sendiri. Dia tidak dipengaruhi, apalagi mengikuti, siapa pun. Yang ada justru sebaliknya, capaian Wayne atas "subjek" dan "tuan" seolah menjadi nilai "ideal" dalam struktur novel Olenka. Oleh karena itu, Wayne sering diacu tokoh-tokoh lain; seperti petanda yang selalu diacu penanda-penanda. Kepada Wayne pula tokoh-tokoh lain tunduk dan menjadi nomor dua. Wayne dipandang sebagai prototipe kebenaran bagi tokoh-tokoh lain; seperti tuturan (prototipe makna) bagi tulisan (penanda tuturan). Di situlah tampak adanya aspek teleologis dalam struktur novel Olenka yang direpresentasikan oleh tokoh Wayne.

Di lain pihak, jika diamati kembali, unsurunsur naratif yang dikonstruksi narator untuk "mengalahkan" tokoh Fanton, Olenka, dan MC adalah [makna fana]; [objek, tunduk, pengikut, berubah-ubah, dan identitas yang tidak jelas]; [tidak penting]; [binatang]; serta [pengganggu]. Sementara itu, unsur-unsur yang melekat pada karakter penanda antara lain: [ketidakhadiran]; [non-alamiah dan tidak otentik]; [di luar atau 
outside]; [biadab]; dan [malapetaka]. Tiga tokoh tersebut memang memiliki unsur oposisi yang diunggulkan dalam masing-masing paradigma mereka. Namun demikian, narator telah membuat mereka salah, kalah, dan gagal melalui berbagai metafora dan ironi sehingga unsur-unsur oposisi tersebut seolah tidak lagi penting.

[Makna fana] identik dengan [ketidakhadiran]. Fanton, dalam introspeksinya, sebenarnya memiliki pandangan mengenai makna hidup. Namun begitu, makna tersebut, rupanya, bukanlah makna sejati sebagaimana makna dalam paradigma narator. Melalui ironi, narator kemudian mengatakan bahwa makna dalam paradigma Fanton hanyalah "makna fana". Karena hanya memiliki pandangan mengenai "makna fana", Fanton dianggap "tidak hadir". Sebab, menurut narator, kehadiran hanya berlaku di dalam makna sejati.

[Objek, tunduk, pengikut, berubah-ubah, dan identitas yang tidak jelas] berhubungan dengan [non-alamiah dan tidak otentik]. Fanton, Olenka, dan MC dinarasikan secara tragis selalu menjadi "objek". Mereka juga "tunduk", baik pada kewajiban maupun kenyataan. Karena bertahan hidup dalam dunia relasi serta berperan hanya sebagai "objek", mereka sering hilang arah sehingga sekadar menjadi "pengikut" orang lain. Mereka kemudian dinilai sebagai produk-produk "non-alamiah" atau tidak murni karena menentukan tujuan bukan atas kehendak diri sendiri. Akhirnya, "identitas mereka tidak jelas"; "berubah- ubah". Dua hal terakhir menjadi penegas bahwa mereka "tidak otentik".

[Tidak penting] identik dengan [di luar atau outside]. Karena paradigma Wayne adalah representasi paradigma narator; Fanton, Olenka, dan MC pun menjadi tidak penting bagi narator. Mereka secara naratif akhirnya tidak bermakna sehingga ditempatkan di luar konstruksi makna narator, sebagaimana posisi tulisan yang selalu berada di luar makna dalam paradigma logosentrisme.

[Binatang] dalam narasi Fanton identik dengan karakter [biadab] tulisan dalam pemahaman Lévi-Strauss. Di hadapan Wayne, Fanton sendiri tidak menyangkal bahwa dirinya tidak lebih dari sekadar "binatang". Fanton menyadari sikapnya yang menuruti hawa nafsu untuk merampas Olenka maupun memukuli Wayne merupakan karakter "biadab".

Sementara itu, [pengganggu] identik dengan [malapetaka]. Persoalan "malapetaka" juga masih berada dalam pandangan LéviStrauss terhadap tulisan. Dia menyatakan bahwa kedatangan tulisan menjadi suatu "malapetaka" bagi suku Nambikwara yang semula damai menjadi sarat kekerasan. Analoginya, Fanton juga menjadi pengganggu bagi identitas kepengarangan Wayne, terutama ketika Fanton masih berupaya untuk berelasi dengan Wayne.

Hal menonjol lain yang perlu diperhatikan, narator mengonstruksi pertentangan antara Wayne dan Fanton sebagai pertentangan antara pengarang dan kritikus. Seperti yang telah dibahas, Fanton dinarasikan sebagai orang 
yang tidak habis-habis menilai Wayne dalam banyak segi; tidak terkecuali karyanya. Namun demikian, Wayne sama sekali tidak menggubris kritik-kritik Fanton. Wayne akhirnya terganggu oleh Fanton hanya karena Fanton masih berusaha membangun relasi pada dirinya.

Secara representatif, narator hendak menganalogikan hubungan dua identitas tersebut dengan hubungan antara tuturan dan tulisan dalam paradigma logosentrisme. Wayne sebagai pengarang identik dengan tuturan, sedangkan Fanton sebagai kritikus identik dengan tulisan. Pengarang, seperti tuturan, tentu lebih dekat-bahkan berhubungan langsung-dengan petanda (makna). Dalam konteks tersebut, petanda atau makna berhubungan erat dengan sebuah karya sastra. Pengarang adalah pencipta ide dan produsen karya sastra. Sementara itu, kritikus, seperti tulisan, tidak memiliki hubungan langsung dengan petanda atau makna. Kritikus hanya bertugas mereafirmasi ide yang telah diciptakan pengarang. Kritikus tidak lebih dari sekadar penjiplak ide, bahkan perusak kemurnian dan ketetapan ide tersebut.

Akhirnya, secara representatif, menurut narator, kritikus justru menjadi semacam suplemen yang membahayakan ide pengarang. Sampai di sini, dapat disimpulkan bahwa unsur-unsur (oposisi) yang dikonstruksi menjadi pusat dalam struktur novel Olenka identik dengan unsur-unsur karakter petanda dalam paradigma logosentrisme.
Dengan kata lain, dalam mengonstruksi struktur novel Olenka, sadar maupun tidak sadar, narator mengusung kembali konsep metaphysic of presence.

\section{Dekonstruksi Struktur Novel Olenka}

\section{Visi, Bakat, dan Klasik Tidak Pernah Hadir}

Struktur yang kukuh menganggap "visi" kepengarangan sebagai sesuatu yang mempunyai kedekatan alamiah dengan petanda (makna) ternyata mendasarkan identitasnya pada "bentuk" (karangan). Dengan kata lain, "bentuk" yang dieksklusi sehingga berada "di luar" sebagai pihak ketiga sebenarnya telah berada "di dalam". Jejak "bentuk" (karangan) selalu mendampingi dan berada di dalam "visi" (identitas pengarang). Dengan demikian, "visi" tidak lebih dari sekadar penanda lain, seperti "bentuk" itu sendiri. Akhirnya, logika originary trace tersebut menghancurkan skema metafisika narator yang bersikeras bahwa "visi" identitas pengarang adalah entitas atau sesuatu yang hadir.

Dalam obsesi Wayne untuk menjadi pengarang, narator juga mengunggulkan "bakat". "Bakat" dianggap sebagai sesuatu yang hadir atau ada (present) oleh narator. Hal itu dapat dilihat melalui pernyataan bahwa "bakat" Wayne tertindih atau terpendam batu karang. Olenka membantu Wayne menjadi Sisipus dalam "upaya" menemukan bakat itu. Wayne merasa telah memperoleh "bakat" tersebut setelah akhirnya karyanya dimuat. Dalam fenomena tersebut, konstruksi narator juga dirusakkan oleh logikanya sendiri. Satu-satunya cara 
mendapatkan "bakat" - kalaupun "bakat" itu ada-adalah mengerahkan "upaya". Artinya, tanpa "upaya”, "bakat” tidak akan pernah ada. Kendati begitu, logika tersebut tidak berarti mengatakan bahwa "bakat" dapat sepenuhnya mengada atau hadir. Sebab, yang ada adalah "upaya". "Bakat" yang hendak mengada masih menunggu dijangkau oleh "upaya".

Selanjutnya, terkait dengan "klasik", secara substansial, perbedaan "klasik" dan "populer" didasarkan pada kuantitas serta ada dan tidaknya orientasi pasar. Orientasi pasar dilekatkan pada penerbit kebanyakan oleh narator. Wayne kemudian dianggap sebagai pengarang "klasik" karena menerbitkan karya pada majalah sastra. Majalah sastra juga dianggap sebagai penerbit "klasik" karena tidak berorientasi pasar. Narator mungkin dapat berapologi bahwa mayoritas masyarakat tidak peduli pada sastra. Kendati begitu, masih ada orang-orang yang menyukai sastra. Orang-orang itulah yang sebetulnya menjadi segmen pasar majalah sastra. Sebab, logisnya, sebuah majalah tidak akan hidup tanpa pembaca. Artinya, seperti penerbit ("populer") kebanyakan, majalah sastra pun berorientasi pasar. Unsur "populer" itulah yang dieksklusi narator sehingga majalah sastra tampak di permukaan sebagai majalah "klasik". Dengan demikian pula, Wayne ikut menjadi pengarang "klasik". Padahal, menurut logika tersebut, "klasik" tidak pernah ada. "Klasik" hanyalah nama lain dari "populer". Keduanya secara naratif akhirnya sama-sama "populer".

\section{Paralelisme Logika Tuan dan Subjek}

Dilihat dari sudut pandang metafisikanya, Wayne sebetulnya tidak pernah hadir sebagai "tuan" maupun "subjek" secara murni dan penuh. Wayne maupun Olenka sama-sama penanda yang saling mengacu. Wayne bisa dihinggapi jejak "subjek" atau "tuan" hanya saat berhubungan dengan Olenka yang dihinggapi jejak "objek" atau "budak". Olenka pun dapat dihinggapi jejak "subjek" atau "tuan" hanya ketika berkaitan dengan Wayne yang dihinggapi jejak "objek" atau "budak". Olenka dapat mendefinisikan identitas Wayne. Wayne dapat menentukan identitas Olenka. Fanton dapat mendefinisikan identitas Wayne. Wayne dapat pula menentukan identitas Fanton. Begitu seterusnya. Makna (petanda) "subjek", “objek", "tuan", maupun "budak" tidak pernah hadir serta mengada secara penuh, murni, alamiah, dan tetap. Sebab, makna-makna tersebut hanya menjadi jejak-jejak dalam hubungan antara penanda-penanda yang saling mengacu, mendefinisikan, serta menggantikan.

\section{Tidak Ada yang di Luar Relasi}

Minggatnya Olenka juga digunakan narator untuk mempresentasikan "independensi" Wayne dalam aktivitas menulis. Peristiwa tersebut justru menunjukkan kontradiksi logika narator yang paling mendasar. Dengan menulis, Wayne otomatis melibatkan diri dalam jaringan tanda. Menurut Derrida, tidak ada tanda yang "independen". Suatu tanda bermakna bukan karena memiliki muatan atau substansi di da- 
lam dirinya, tetapi karena tanda berbedasecara fonetis maupun konseptual-dari tanda lain di dalam sistem linguistik. Tanda yang tampaknya tunggal, hadir, dan "independen" ternyata mengandung jejakjejak (traces) tanda lain di dalam sistem yang mendefinisikannya.

Logika narator yang mengistimewakan Wayne melalui "independensi" sehingga menganggapnya hadir atau ada secara penuh dan tunggal menjadi runtuh. Sebab, tidak ada yang di luar teks (there is no outside-text). Karena teks bersifat relasional, dependen, dan plural, tidak ada yang di luar "relasi", dependensi, dan pluralitas. Artinya, jika tetap "independen", Wayne sama sama saja tidak hadir (ada). Apabila tetap dianggap beridentitas tunggal, Wayne juga sama saja tidak hadir (ada). Mengunggulkan Wayne dengan menempatkannya dalam "independesi" (di luar "relasi"), sebenarnya, secara bersamaan, membuat Wayne tidak hadir (ada). Hal tersebut semakin mengukuhkan pola paradoksikal logika narator: yang sebenarnya tidak present menjadi present.

\section{Simpulan}

Penelitian ini memperoleh simpulan bahwa novel Olenka dikonstruksi secara logosentris oleh narator. Logosentrisme itu terepresentasi dari struktur novel yang didasarkan pada kehadiran, konsistensi (tetap), kestabilan, independensi, serta kebenaran. Elemen-elemen metafisik tersebut hanya melekat pada seorang tokoh, yaitu
Wayne Danton. Tokoh-tokoh lain-Fanton Drummond, Olenka, dan Mary Carson (MC)dinarasikan mengandung oposisi dari elemenelemen metafisik tersebut, yakni ketidakhadiran, inkonsistensi (goyah), instabilitas, dependensi, maupun kesalahan (kesengsaraan). Pemosisian Wayne sebagai senter kemudian menunjukkan bahwa narator telah mereproduksi metaphysic of presence melalui novel Olenka.

Dalam perjalanan analisis, logosentrisme dalam novel tersebut cukup sulit ditangkap. Sebab, narator mengemas jaringan oposisi pembentuk struktur secara skematis. Caranya, menyembunyikan paradigma logosentrisnya di balik kemelut relasi antartokoh. Politik eksklusi dan inklusi berperan banyak dalam penyembunyian paradigma itu. Paradigma narator akhirnya terepresi oleh paradigma tokoh-tokoh yang sering bergeser. Bahkan, jaringan oposisioposisi dalam struktur novel saling berbenturan sehingga di permukaan, narator justru tampak membawa semangat pascastrukturalis dengan kredo antilogosentrisme.

Meski demikian, tentu, kesan itu hanya tampak dari permukaan. Setelah mengangkat kembali paradigma narator yang direpresi, lalu melakukan desedimentasi terhadapnya dengan cara mengategorikan jaringan oposisi berdasar paradigma masing-masing tokoh, tulisan ini akhirnya dapat menangkap logosentrisme dalam struktur novel Olenka. Berangkat dari temuan tersebut, dekonstruksi dilakukan. Hasilnya, elemen-elemen yang memosisikan 
Wayne sebagai senter dalam struktur novel Olenka tampak superior karena narator mengeksklusi elemen-elemen yang dianggap mengancam superioritas itu. Kendati demikian, setelah logika kontradiktif, paradoksikal, dan inkonsisten narator ditemukan lewat dekonstruksi, elemen-elemen yang dianggap superior itu ternyata sangat bergantung pada elemen-elemen yang dieksklusi. Misalnya, subjek bergantung pada objek dan tuan bergantung pada budak. Wayne akhirnya dapat dikatakan tidak pernah hadir secara murni karena kehadiran tersebut ditentukan oleh tokoh-tokoh lain. Dengan demikian, identitasnya juga tidak pernah hadir atau ada (secara penuh). Kalaupun ada, identitas hanyalah jejak penanda yang selalu bergerak, berubah, terus-menerus mengacu dan dependen terhadap penanda selanjutnya, serta tidak akan pernah memperoleh makna yang final atau absolut. Konstruksi struktur novel Olenka yang mengistimewakan Wayne dan menempatkannya menjadi senter karena memiliki identitas yang tetap, stabil, penuh, murni, tunggal, final, dan absolut kemudian tersangkal oleh logikanya sendiri.
Bradley, Arthur. 2008. Derrida's Of Grammatology. Edinburgh-Scotland: Edinburgh University Press.

Darma, Budi. 2009. Olenka. Jakarta: PT Balai Pustaka.

Darma, Budi. 2017. Kritikus Adinan. Yogyakarta: Bentang Pustaka.

Derrida, Jacques. 1976. Of Grammatology. Translated by Gayatri Chakravorty Spivak. Baltimore-Maryland: The Johns Hopkins University Press.

Faruk. 2012. Metode Penelitian Sastra: Sebuah Penjelajahan Awal. Yogyakarta: Pustaka Pelajar.

Indraningsih. 1996. "Eksistensi Manusia dalam Rafilus dan Olenka Karya Budi Darma: Sebuah Kajian Semiotik". MA the, Universitas Gadjah Mada, Yogyakarta.

Suwondo, Tirto. 2000. "Olenka: Tinjauan Dialogis". MA the, Universitas Gadjah Mada, Yogyakarta.

Suwondo, Tirto. 2001. Suara-Suara yang Terbungkam: Olenka dalam Perspektif Dialogis. Yogyakarta: Penerbit Gama Media.

Suwondo, Tirto. 2001. "Olenka, Chairil Anwar, dan Sartre: Kajian Dialogis". Pangsura, Juli-Desember 2001, Bilangan 13/Jilid 7: $33-48$.

Suwondo, Tirto. 2002. "Budi Darma Menggarap Jiwa Manusia Berdasarkan Takdirnya". Horison (Kaki Langit) Januari 2002.

Suwondo, Tirto. 2011. Membaca Sastra, Membaca Kehidupan. Yogyakarta: Hikayat Publishing.

\section{Daftar Pustaka}

